\title{
Part-Time Work and Gender Inequality in Europe. A Comparative Analysis of Satisfaction with Work-Life Balance*
}

\author{
Barbara Beham \\ Berlin School of Economics and Law \\ Sonja Drobnič \\ University of Bremen \\ Patrick Präg \\ University of Oxford and Nuffield College \\ Andreas Baierl \\ University of Vienna \\ Janin Eckner \\ Berlin School of Economics and Law
}

April 2018

\begin{abstract}
Part-time work is an increasingly common strategy for handling work and family - but is it an effective strategy everywhere and for everyone? To answer this question, we examine the satisfaction with work-life balance of workers in 22 European countries included in round five of the European Social Survey. Our results show that part-time workers are more satisfied with their work-life balance than full-time workers; the more so, the fewer hours they put in. Yet, we find an important gender difference: Women in marginal part-time work (less than 21 hours/week) are more satisfied than men in a similar situation, and conversely men
\end{abstract}

*This manuscript was published on July 1, 2019 in European Societies 21(3), pp. 378-402, doi:10.1080/14616696.2018.1473627. 
in full-time work are more satisfied than women working full-time. Further, the societal context plays an important role: substantial part-time work (21-34 hours/week) is more conducive to satisfaction with work-life balance in more gender-egalitarian countries than in countries with low gender equality. Hence, a supportive gender climate and institutional support may entice workers to reduce working hours moderately, which results in markedly increased levels of SWLB.

\section{Introduction}

In many European countries, reduced working hours have become a common strategy for employees to manage their work and family responsibilities and to reach a satisfying level of balance between the different life spheres (Bielenski et al., 2002; Gornick and Heron, 2006; Lyonette, 2015). The expansion of part-time work can be a positive development if it reflects a genuine choice of people balancing between work and other life pursuits, or if it increases employment opportunities for those previously excluded from the labor market, such as mothers or older workers. But part-time work can also be involuntary because no full-time job is available or it is the only available option because of the difficulty of reconciling a 'standard' job with one's family responsibilities (e.g. Baierl and Kapella, 2014; Gash, 2008; Lyonette, 2015).

Although the overall proportion of part-time workers has steadily increased in almost all parts of Europe in the last decades, part-time employment is a highly gendered phenomenon. It is mainly women who reduce their working hours after childbirth in order to balance work and caring responsibilities. In 2016, 31 per cent of female employees worked part-time in the European Union as compared to eight per cent of men (Eurostat, 2018, 'lfsa_pt_a'). Further, the prevalence of part-time work differs significantly across European countries. Part-time is most common in countries where social policies and/or norms regarding the role of men and women in society strongly support reduced working hours (especially among females), such as The Netherlands, Germany, Austria, Belgium, Switzerland, and the UK. Despite strong policy support for work-family reconciliation and less traditional gender norms in the Nordic countries, part-time work is also widespread in Norway and Sweden. Part-time work is less common in the Mediterranean and the Eastern European countries, where policy support for work-family balance is lower and part-time work is not widely offered by employers (Baierl and Kapella, 2014; Fahlén, 2014).

Part-time workers report less work-family conflict and greater satisfaction with their work-family balance (Beham et al., 2011, 2012; Oishi et al., 2015; Roeters and Craig, 2014; Sándor, 2013). Although it is evident that shorter work time can provide greater flexibility to accommodate competing work and life demands, the question arises whether part-time work is a viable path to a 
satisfying work-life balance in every European society and for everyone. Individuals hold different norms and attitudes, just as societies differ in institutional arrangements and the normative climate they provide. Given the gendered nature of part-time work in Europe, it might well be possible that employees' gender and the gender norms of their social context shape the pathway between part-time work and a satisfying work-life balance. The crucial role of gender has long been recognized in research examining antecedents and consequences of part-time employment (e.g. Beham et al., 2012; Blossfeld and Hakim, 1997; Gash, 2008; Gash et al., 2012; Lyonette, 2015; Rosenfeld and Birkelund, 1995; Webber and Williams, 2008). Still, there is only limited empirical evidence on how gender and gender inequality at the societal level influences the relationship between part-time employment and the work-family interface. The few existing findings on gender differences are not clear cut. Whereas Beham et al. (2012) reported no significant gender difference in the link between parttime work and satisfaction with work-family balance, Sándor (2013) concluded that women working part-time were more satisfied with their work-life balance but the gender gap decreased as hours of employment increased. Further, research has shown that societal gender norms, heightened expectations in some institutional contexts, and governmental support for work-family reconciliation influence employees' work-life experiences and shape the work-family interface (Fahlén, 2014; Hagqvist et al., 2017; Ruppanner and Huffman, 2014; Ruppanner and Maume, 2016). Nevertheless, an empirical examination of how societal gender climate shapes the relationship between reduced working hours and work-life balance across different countries is still missing.

To address this gap in the literature, the present study investigates whether gender at the individual level and gender equality at the societal level alter the relationship between part-time work and satisfaction with work-life balance. By analyzing probability samples of the working populations in 22 European countries, we extend previous research on part-time employment in several ways. Firstly, other studies were limited to fewer countries and non-representative samples (Beham et al., 2012). Secondly, we acknowledge the varied nature of parttime arrangements by distinguishing between marginal and substantial parttime employment. Part-time employment is not a homogeneous phenomenon but it differs in nature and in outcomes (e.g. Beham et al., 2012; Bielenski et al., 2002; Blossfeld and Hakim, 1997; Roeters and Craig, 2014). Thirdly, we will provide more conclusive results on gender differences in part-time employment and satisfaction with work-life balance by not only examining differences between men and women, but by also analyzing how these differences are shaped by national-level gender inequality. Finally, our study contributes to the growing body of cross-national comparative research on the work-family interface which aims to put employees' work-life experiences into context, thereby ac- 
knowledging that the interface is shaped by its societal context (Beham et al., 2014, 2018; Ollier-Malaterre et al., 2013; Präg and Mills, 2014; Ruppanner and Huffman, 2014; Ruppanner and Maume, 2016).

\section{Theoretical background}

\section{Satisfaction with work-life balance}

Despite its popularity in business media and the popular press, the concept of work-life balance (WLB) has only recently received more attention by academic scholars and has been acknowledged as a unique construct and useful addition to the literature on the work-family interface (Wayne et al., 2017). Whereas early definitions framed WLB as an individual choice and a personal responsibility (thereby neglecting structural, cultural, and gendered constraints), more recent definitions understand WLB as a social construct that is shaped by both individual and contextual factors (Drobnič and Guillén Rodríguez, 2011). Consistent with role balance theory, Grzywacz and Carlson (2007, p. 458) defined WLB as 'the accomplishment of role-related expectations that are negotiated and shared between an individual and his or her role-related partners in the work and family domain.' Greenhaus and Allen (2011) defined WLB as when effectiveness in and satisfaction with work and family are consistent with one's life priorities. Across the various definitions, WLB is conceived as a global evaluation of the interplay between work and private life (Carlson et al., 2009; Wayne et al., 2017).

Following recent suggestions to conceptually and empirically differentiate between effectiveness at and satisfaction with balancing work and private life Grzywacz and Carlson (2007); Wayne et al. (2017), the present study focuses on employees satisfaction with work-life balance (SWLB). SWLB is a unitary and holistic construct (Valcour, 2007). It has been negatively linked to a variety of job demands (including working hours, commuting time, job insecurity) and positively associated with job resources such as job control and social support at work (Abendroth and den Dulk, 2011; Beham and Drobnič, 2011; McNamara et al., 2013; Valcour, 2007).

Although part-time work has often been criticized for poor job quality in terms of lower status, job security and pay, fewer training and career opportunities, and for reproducing a gendered division of labor (e.g. Lyonette et al., 2010; Warren, 2004, 2008), employees working reduced hours seem to experience less negative interference between work and family and higher levels of SWLB (Beham et al., 2012; Oishi et al., 2015; Roeters and Craig, 2014). These findings are in line with the scarcity argument in role theory (Goode, 1960), which argues that long working hours create conflict in employees, since individuals only have a finite amount of time which they can either devote to work or private 
matters (Greenhaus and Beutell, 1985). Consequently, reducing working hours is a prominent means (especially among young mothers) to free time for private and family matters, and to reduce conflict and increase WLB (Lyonette, 2015).

Nevertheless, part-time work may differ with respect to actual working hours and thus influence employees' opportunities to reach a satisfying level of reconciliation between work and non-work obligations differently. In line with previous research which distinguishes between substantial (long-hours) and marginal (short-hours) part-time work (Beham et al., 2012; Bielenski et al., 2002; Roeters and Craig, 2014), we suggest that employees working a marginal part-time schedule of up to 20 hours/week are more satisfied with their WLB than workers who work a substantial part-time schedule between 21 and 34 hours/week. Consequently, it is hypothesized:

Hypothesis 1: Part-time workers are more satisfied with their worklife balance than full-time employees. The difference is greater for marginal part-time workers than for substantial part-time workers.

\section{Part-time employment and gender}

Although gender roles are changing, women continue to be primarily responsible for childcare and housework (Treas and Drobnič, 2010). Women (especially those with young children) are more likely to reduce their working hours in order to be better able to manage their multiple responsibilities at home and at the workplace, even at the expense of poorer working conditions and limited career prospects (Beham et al., 2012; Gash et al., 2012; Lyonette, 2015; Webber and Williams, 2008). Men, on the other hand, more frequently work parttime while in education and training or because they are not able to find fulltime employment (Baierl and Kapella, 2014). According to the 2010 European Union Labor Force Survey, these were the most common reasons for part-time employment among men in the European countries examined in this study. The most frequently reported reasons of women to work part-time were childcare and other family or personal reasons accounting for 43 per cent in total, as opposed to 16 per cent for men (Eurostat, 2018, 'lfsa_epgar'). These gender differences in motivation for being in part-time employment may influence men and women's opportunities for WLB differently. Whereas women seem to more frequently opt for reduced working hours to increase their opportunities for reaching a satisfying level of WLB, this seems to be less the case for men and consequently may not result in comparable levels of SWLB among men.

Even though more women reduce their working hours for family reasons, the empirical evidence on whether part-time working women experience less conflict and higher levels of SWLB than men is not clear-cut. Whereas Sándor 
(2013) reported women working a marginal part-time schedule to report higher levels of SWLB than men, a study among service sector employees in five Western European countries did not yield any gender differences in SWLB for both marginal and substantial part-time workers (Beham et al., 2012). To gain additional insights into these relationships, we provide a more powerful test of gender differences in the relationship between part-time work and SWLB, using a sample that is not restricted to the service sector and includes countries from all of Europe. Despite growing expectations on men to become more involved in household and care-giving tasks (Fahlén, 2014), women are still the primary caregivers and consequently face more difficulties than men in living up to the ideal worker norm of long working hours and minimal accommodations for private life. A reduction of working hours is thus a more viable option for women, especially when a substantial reduction in working hours is necessary to meet non-work obligations. In normative terms, working a marginal part-time schedule may comply more with the female caregiver role and less with the male breadwinner role. Consequently, we hypothesize:

Hypothesis 2: Female part-time workers are more satisfied with their work-life balance than male part-time workers. We expect the gender difference to be greater for marginal part-time work than for substantial part-time work.

\section{Societal gender equality}

Countries vary in regard to gender norms and the relative position of men and women in politics, education, and the labor market (Fahlén, 2014; UNDP, 2010). Societal beliefs and norms about the appropriate roles for men and women influence men's and women's employment options and shape their opportunities to achieve work-life balance (Lyness and Judiesch, 2014; Pfau-Effinger, 2012; Uunk, 2015). In more gender-equal countries, traditional gender roles are less emphasized and both men and women are equally encouraged to engage in work and family roles. In countries low on gender equality, the traditional male breadwinner, female carer social model prevails (McDaniel, 2008).

Gender norms and institutional context are interconnected (Fahlén, 2014). Gender norms are shaped by institutions, such as the family, labor market and the welfare state. But the welfare state also constitutes gender relations and responds to existing gender norms (Gregory and Milner, 2008; Mandel, 2009). These interrelations are particularly evident in Europe. The Nordic countries are characterized by the least traditional gender norms, high levels of gender equality and extensive statutory support for work-family reconciliation. Both social policies and societal norms encourage a more equal division of caring and working responsibilities in these countries. This is also reflected in the part- 
time employment rates in the Nordic countries. Although women reduce their working hours to a larger extent than men (and they mainly do so for family and personal reasons), male part-time rates are above the EU average in these countries (Eurostat, 2018; Drange and Egeland, 2014).

More traditional gender norms and lower levels of gender equality can be found in the Eastern European countries, where the state provision for childcare is low and part-time employment is not very common. In former socialist countries, part-time employment was rare and not considered a female phenomenon (Drobnič, 1997). In the post-transition period, part-time employment is infrequent, most families need a full-time wage, and there is no established gender ideology whereby women are expected to work part-time instead of fulltime. Consequently, part-time employment among both sexes is well below the EU average in these countries (Eurostat, 2018, 'Ifsa_pt_a'). Furthermore, and in contrast to the Nordic countries, part-time work is less often a deliberate choice to increase work-family balance but rather the result of unfavorable labor market conditions and a lack of full-time employment opportunities (Baierl and Kapella, 2014; Eurostat, 2018; Sándor, 2013). To some extent this parallels the situation in the Mediterranean countries, especially in the aftermath of the financial crisis starting in 2008. We observe slightly higher part-time employment rates in the Mediterranean countries, mainly due to larger proportions of female part-time workers. However, the shortage of full-time jobs accounts for a considerable share of part-time employment among men and women in these countries (Eurostat, 2018, 'lfsa_pt_a' and 'lfsa_epgar'). Furthermore, women's reduction of working hours is less a deliberate choice for personal reasons (as in the Nordic countries) but rather a necessity to compensate for a lack of statutory support for work-life balance. Despite some recent changes, the family continues to be the main caregiver in the sub-protective welfare state regime of the Mediterranean countries (Kovacheva et al., 2011).

There is a relatively strong governmental support for women to reduce their working hours for family responsibilities in many Western European countries such as Austria, Switzerland, Germany, The Netherlands, and the UK despite less traditional gender roles (Fahlén, 2014; Pollmann-Schult, 2016). In these countries, a modified male breadwinner model is promoted and shorter parttime working hours ( $<20$ hours per week), especially among mothers, are more common than in the Nordic countries where longer part-time hours are most frequent (Fahlén, 2012; Kovacheva et al., 2011; Mills et al., 2014b; PollmannSchult, 2016). Among these societies, The Netherlands assume a unique position as highly gender egalitarian society (see Gender Inequality Index in Table 1) with the highest part-time employment rates for both men and women in Europe (Eurostat, 2018, 'lfsa_pt_a').

Gender norms and the institutional context do not only shape employ- 
ment opportunities but also shape people's expectation regarding WLB and these expectations may influence their levels of satisfaction with WLB (Fahlén, 2014; Ruppanner and Maume, 2016). In high gender equality and more familysupportive contexts, individuals may be more sensitive to work-life interference and have higher expectations for WLB. However, if these expectations are not met, greater disappointment may occur. In a study of working hours and workto-family conflict among workers in 32 countries, Ruppanner and Maume (2016) found support for their 'heightened expectations' argument. Workers reported more work-to-family conflict in countries with shorter work hours due to unmet expectations for higher levels of WLB. When aiming at a satisfying level of WLB, individuals respond to the institutional context and expectations as well as to demands and resources at the workplace (Fahlén, 2014). For example, workers reported greater WLB in more expansive dual-earner and gender-egalitarian (the Nordic) countries than in countries with a more traditional division of labor such as the UK and Ireland, but also Germany and Austria (Grönlund and Öun, 2010). Assuming that a reduction of working hours is a common response and means to achieve WLB, employees may respond with a stronger reduction of working hours in less gender-egalitarian and less work-family supportive countries. In more egalitarian countries, where extensive support for work-life reconciliation is available, employees may have a preference for working longer working hours, hence substantial part-time arrangements. Research on working mothers in Europe has indeed shown that gender equality at the societal level mitigates the negative impact of children on women's preference to reduce their working hours (Pollmann-Schult, 2016). Further, a liberal gender ideology has been found to narrow the gap in happiness between wives working longer and shorter hours, thereby alleviating some disadvantages associated with working longer hours (Treas et al., 2011). Consequently, we assume that employees working a substantial part-time schedule are more satisfied with their WLB in high gender-egalitarian than in low gender-egalitarian countries. However, due to heightened expectations for WLB in countries high in gender equality, we expect the difference in SWLB between full-time and substantial part-time workers to be larger in these countries than in the less gender-egalitarian countries where expectations on work-family balance are also low. Consequently, it is hypothesized:

Hypothesis 3: Substantial part-time workers are more satisfied with their work-life balance in more gender-egalitarian countries than in low gender-egalitarian countries. The gap in SWLB between substantial part-time work and full-time employment is larger in more gender-egalitarian countries. 


\section{Data and methods}

\section{Sample and procedure}

Data of the fifth round of the European Social Survey (ESS) were used for testing the study hypotheses. The ESS is a large scale, biennial cross-national survey conducted via face-to-face interviews in various European countries. The 2010 data included a special module on work-life balance. Due to the small share of part-time workers in some country samples, we were not able to perform a meaningful comparison with the data from Croatia, Slovenia, and Slovakia. Consequently, we excluded these countries from our analysis. Further, we had to exclude Ukraine because country-level data on the provision of formal childcare was not available for this country. Country-level data we use are the Gender Inequality Index (UNDP, 2010), provision of childcare for children aged 0-2 years (Eurostat, 2018, 'ilc_ca'), and involuntary part-time work (OECD, 2018).

Our final sample comprises 14,097 employees working in various industries in 22 European countries. Country samples sizes range from $N=222$ in Cyprus to $N=1,204$ in Germany. Average age of respondents was 42.3 years and 52.9 per cent had at least one child living in the same household. Table 1 provides an overview of country samples sizes, shares of women and part-time workers in the sample, as well as the country means of the outcome SWLB. In addition, the share of children aged 0-2 years in formal childcare, the proportion of involuntary part-time employment, and the Gender Inequality Index per country are presented.

\section{Measures}

Outcome SWLB was measured with the single item 'How satisfied are you with the balance between the time you spend on your paid work and the time you spend on other aspects of your life?' The response scale ranged from 'extremely dissatisfied' (0) to 'extremely satisfied' (10).

Key independent variables Marginal part-time work $(<21$ hours/week) and substantial part-time work (21-35 hours/week) were dummy-coded, with 1 indicating that the employee works the respective part-time schedule. Full-time employment is the reference category in all multivariate models.

Moderators Gender is dummy-coded with 1 denoting female, and 0 male. The Gender Inequality Index 2010 of the United Nations was used as the country-level indicator for gender (in)equality and included as a moderator variable in our models. The GII is a composite measure of objective indicators reflecting gender inequality in reproductive health, female empowerment, 


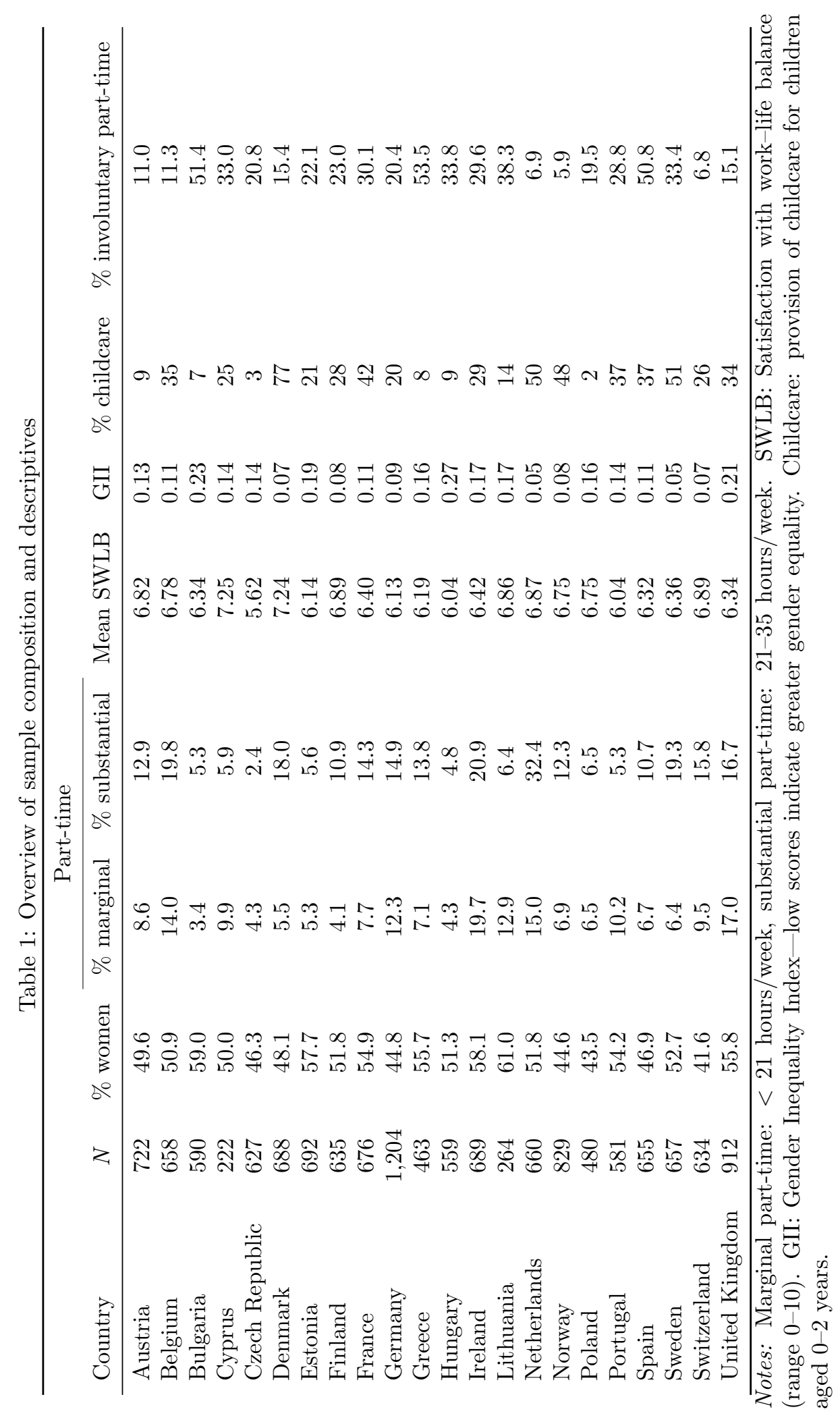


and labor force participation (UNDP, 2010). It replaces previous gender development and empowerment measures and reveals the extent to which the realization of a country's human development potential is confined by gender inequality. Unlike other gender equality indices (e.g. the Gender Gap Index of the World Economic Forum) which only assess gender gaps, the GII also takes into account absolute achievements, thereby leading to more accurate country rankings (Gaye et al., 2010). Higher GII scores indicate more gender inequality at the country-level.

Controls We controlled for various individual-level work demands and resources, since their impact on SWLB has been shown in previous research (Beham et al., 2012). Overtime was calculated as the difference between actual and contracted working hours. Work and time pressure were assessed with a single item each on a 5-point Likert scale. Job control was measured with two items on an 11-point scale, ranging from 'I have no influence' (0) to 'I have full control' (10). Cronbach's alpha for the scale was .81. Co-worker support was measured with the single item on a 4-point scale.

Further we controlled for age groups (reference category is 60 years and older in all models), marital status $(1=$ married/cohabiting, $0=$ single $)$, parental status $(1=$ children, $0=$ no children $)$, professional status ${ }^{1}(1=$ professional, 0 $=$ non-professional), and respondents' feeling about their income, ranging from 'finding it very difficult on present income' (1) to 'living comfortably on present income' (4). Higher scores indicate higher economic wellbeing. At the country level, we included the percentage of children aged 0-2 years in formal childcare and the share of involuntary part-time workers in the year of data collection as control variables. Availability of childcare outside the home should allow parents to better cope with the competing time claims in family and work and more freely exert their preferences concerning the length of working time, thus increasing their satisfaction with work-life balance (Mills et al., 2014a). The notion of involuntary part-time work entails a constraint on workers' desired labor supply and can lead to dissatisfaction with part-time work arrangements and the perceived work-life balance.

\section{Analytical strategy}

To account for the nested structure of our data (14,097 employees nested in 22 countries), we make use of multilevel (random coefficient) regression. The in-

\footnotetext{
${ }^{1}$ ISCO-88 codes, supervisor status, and number of employees under supervision were used to assign participants to the EGP class schema (Erikson and Goldthorpe, 1992) which allows for comparative analyses between different employee categories. 'High and low controllers' were collapsed into a new category 'professionals.' The EGP classes 'routine non-manual,' 'routine manual,' 'skilled-manual,' 'semi-unskilled manual,' 'skilled manual,' 'manual supervisor,' and 'farm labor' were classified as 'non-professionals.' Self-employed and small employers were not included in our sample.
} 
traclass correlation coefficient $(I C C)$ for the dependent variable SWLB is rather low $(I C C=4$ per cent), meaning that the bulk of variance is located at the individual level. Nevertheless, HLM is recommended due to more correct estimations of standard errors (Gelman and Hill, 2007). To enhance model estimation and the interpretation of results (especially the cross-level interaction terms), level-1 variables were country-mean centered and level-2 variables were grandmean centered. To improve model fit, we included random slopes of level-1 covariates which varied significantly across countries (Heisig et al., 2017). This was the case for professional status, overtime, time pressure, co-worker support, and job control. However, these slope variances are not displayed in the table (but are available upon request).

Further, we followed Mills and Präg's (2016) recommendations to strengthen cross-level analysis by supplementing multilevel analysis with an alternative two-step regression analysis. This approach is particularly recommended in case of multilevel country data with large country samples and a rather small range of countries. In a first step, the effects of part-time work on SWLB were estimated separately for each country. In a second step, we regressed these parttime coefficients on GII. This corresponds to the cross-level interaction between marginal part-time work/substantial part-time work and GII, the effect that is of main concern in Hypothesis 3. Two-step regression allows a straightforward visualization of the cross-level interaction effect.

\section{Results}

Table 2 reports unstandardized regression coefficients, standard errors, variance components, and deviances for the random slope models predicting SWLB.

In support of Hypothesis 1 (Model 1), both marginal part-time workers $(b=.76, p<.01)$ and substantial part-time workers $(b=.44, p<.01)$ reported significantly higher SWLB than full-time workers and the effect was stronger for marginal part-time workers. A separate analysis based on the sub-sample of part-time workers (analysis not presented but available upon request from the authors) confirmed that marginal part-time workers $(b=.37, p<.01)$ experience higher levels of SWLB than employees working a substantial part-time schedule. The negative regression coefficient for gender in all models indicates that women were less satisfied with their WLB than men. The negative, significant regression coefficients for all age groups suggest that all younger age groups reported lower SWLB than the group of employees older than 60 years. Whereas economic wellbeing and both job resources (job control and co-worker support) were positively related to SWLB, work demands were negatively related to SWLB.

In Hypothesis 2, we proposed that women working part-time would report 
Table 2: Satisfaction with work-life balance regressed on part-time work, random coefficient model, $N=14,097$.

\begin{tabular}{|c|c|c|c|c|c|c|}
\hline & \multicolumn{2}{|c|}{ Model 1} & \multicolumn{2}{|c|}{ Model 2} & \multicolumn{2}{|c|}{ Model 3} \\
\hline & $b$ & $S E$ & $b$ & $S E$ & $b$ & $S E$ \\
\hline \multicolumn{7}{|l|}{ Working time (Ref. full time) } \\
\hline Marginal part-time & $.76^{* *}$ & .08 & $.70^{* *}$ & .08 & $.71^{* *}$ & .08 \\
\hline Substantial part-time & $.44^{* *}$ & .07 & $.41^{* *}$ & .07 & $.38^{* *}$ & .06 \\
\hline Female (Ref. male) & $-.15^{* *}$ & .03 & $-.14^{* *}$ & .03 & $-.14^{* *}$ & .03 \\
\hline \multicolumn{7}{|l|}{ Age (Ref. $>60$ years) } \\
\hline$<30$ years & $-.46^{* *}$ & .08 & $-.46^{* *}$ & .08 & $-.46^{* *}$ & .08 \\
\hline 30-39 years & $-.46^{* *}$ & .08 & $-.47^{* *}$ & .08 & $-.48^{* *}$ & .08 \\
\hline 40-49 years & $-.31^{* *}$ & .08 & $-.32^{* *}$ & .08 & $-.32^{* *}$ & .08 \\
\hline $50-60$ years & $-.21 * *$ & .08 & $-.22^{* *}$ & .08 & $-.22^{* *}$ & .08 \\
\hline Married/cohabiting (Ref. single) & -.02 & .04 & -.03 & .04 & -.03 & .04 \\
\hline Parent (Ref. no children) & -.02 & .04 & -.02 & .04 & -.02 & .04 \\
\hline Professional (Ref. non-professional) & .06 & .05 & .06 & .05 & .07 & .05 \\
\hline Economic wellbeing & $.35^{* *}$ & .02 & $.35^{* *}$ & .02 & $.35^{* *}$ & .02 \\
\hline Overtime & $-.04^{* *}$ & .00 & $-.04^{* *}$ & .00 & $-.04^{* *}$ & .00 \\
\hline Work pressure & $-.17^{* *}$ & .02 & $-.17^{* *}$ & .02 & $-.17^{* *}$ & .02 \\
\hline Time pressure & $-.28^{* *}$ & .03 & $-.28^{* *}$ & .03 & $-.28^{* *}$ & .03 \\
\hline Job control & $.08^{* *}$ & .01 & $.08 * *$ & .01 & $.08^{* *}$ & .01 \\
\hline Co-worker support & $.30^{* *}$ & .03 & $.30^{* *}$ & .03 & $.30^{* *}$ & .03 \\
\hline \multicolumn{7}{|l|}{ Level-1 interaction } \\
\hline Marginal part-time $\times$ Female & & & $.33^{* *}$ & .13 & $.34^{* *}$ & .13 \\
\hline Substantial part-time $\times$ Female & & & .17 & .12 & .17 & .11 \\
\hline \multicolumn{7}{|l|}{ Level 2} \\
\hline Gender Inequality Index (GII) & & & & & -1.17 & 1.88 \\
\hline$\%$ childcare & & & & & .01 & .01 \\
\hline$\%$ involuntary part-time & & & & & .00 & .01 \\
\hline \multicolumn{7}{|l|}{ Cross-level interaction } \\
\hline Marginal part-time × GII & & & & & .87 & 1.34 \\
\hline Substantial part-time $\times$ GII & & & & & $-2.52^{* *}$ & .91 \\
\hline Intercept & $6.48^{* *}$ & .09 & $6.47^{* *}$ & .09 & $6.48^{* *}$ & .08 \\
\hline Variance(Intercept) & \multicolumn{2}{|c|}{$.17^{* *}$} & \multicolumn{2}{|c|}{$.17^{* *}$} & \multicolumn{2}{|c|}{$.14^{* *}$} \\
\hline Variance(Marginal part-time) & \multicolumn{2}{|c|}{.05} & \multicolumn{2}{|c|}{.04} & \multicolumn{2}{|c|}{.04} \\
\hline Variance(Substantial part-time) & \multicolumn{2}{|c|}{.02} & \multicolumn{2}{|c|}{.02} & \multicolumn{2}{|c|}{.00} \\
\hline Deviance & \multicolumn{2}{|c|}{$58,058.07$} & \multicolumn{2}{|c|}{$58,054.69$} & \multicolumn{2}{|c|}{$58,050.78$} \\
\hline
\end{tabular}

Notes: $* p<.05, * * p<.01$. 


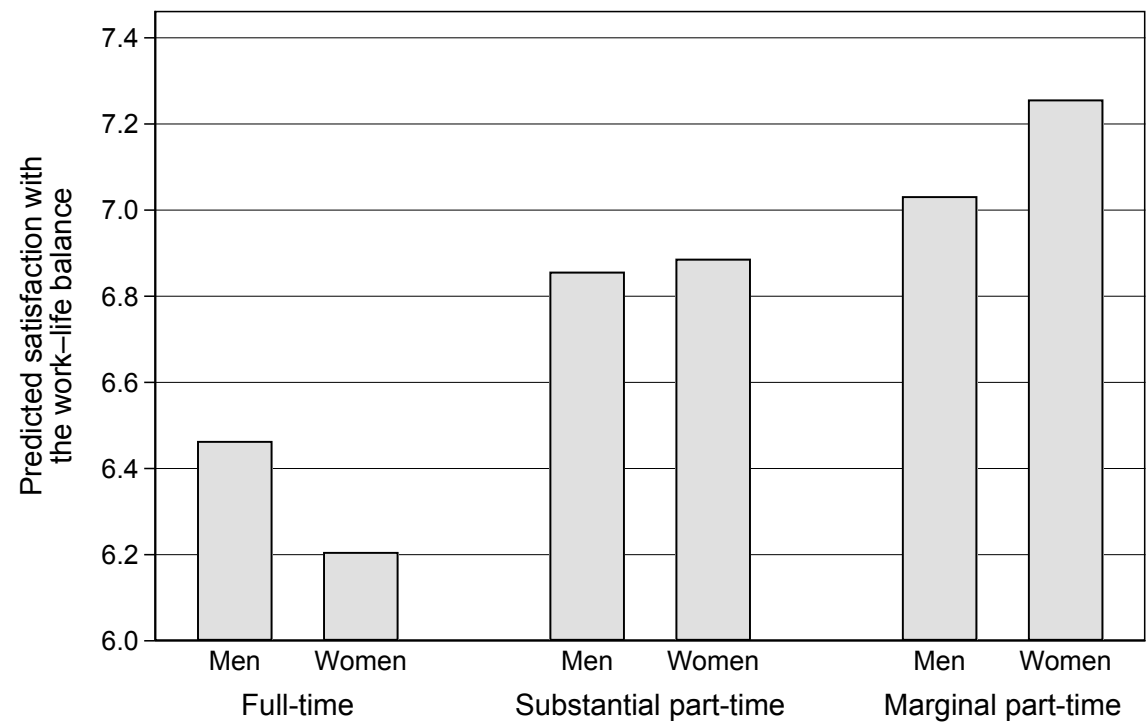

Figure 1: Part-time workers are more satisfied with their work-life balance than full-time employees, particularly females on a marginal part-time schedule. Predictions based on Model 2 of Table 2.

more SWLB than men and that this difference would be greater for women working marginal part-time. Our analysis partially confirmed this hypothesis. We found a significant interaction for marginal part-time work $\times$ gender on $\operatorname{SWLB}(b=.33, p<.01 ;$ Model 2$)$. Figure 1 shows that women working marginal part-time report more SWLB than men working marginal part-time. In line with predictions, the gender difference was larger for marginal part-time than for substantial part-time work. Figure 1 also illustrates the non-significant interaction term for substantial part-time work. When working full-time, men are significantly more satisfied with their WLB than women. Hence the significant SWLB advantage of men in our models is mainly driven by the lower levels of SWLB among full-time working women.

We conducted a number of robustness checks (available upon request) to account for alternative explanations of our findings, such as 1) higher SWLB due to preparation for retirement or 2) lower SWLB because of being pushed out of the labor market due to gender discrimination. We estimated Model 2 including several interaction terms between age groups and both forms of parttime work and with alternating reference groups. Since no significant differences across age groups were detected, we concluded that the alternative explanation 1) does not apply to our sample. In a second step, we added three-way interactions for age groups, gender, and both forms of part-time work. Our analysis yielded significant interaction terms for marginal part-time work in the middle 
age groups (30-49 years) and in favor of our female part-time workers, which is indicative of the opposite effect rather than a push-out effect due to gender discrimination, as alternative explanation 2) had posited.

A

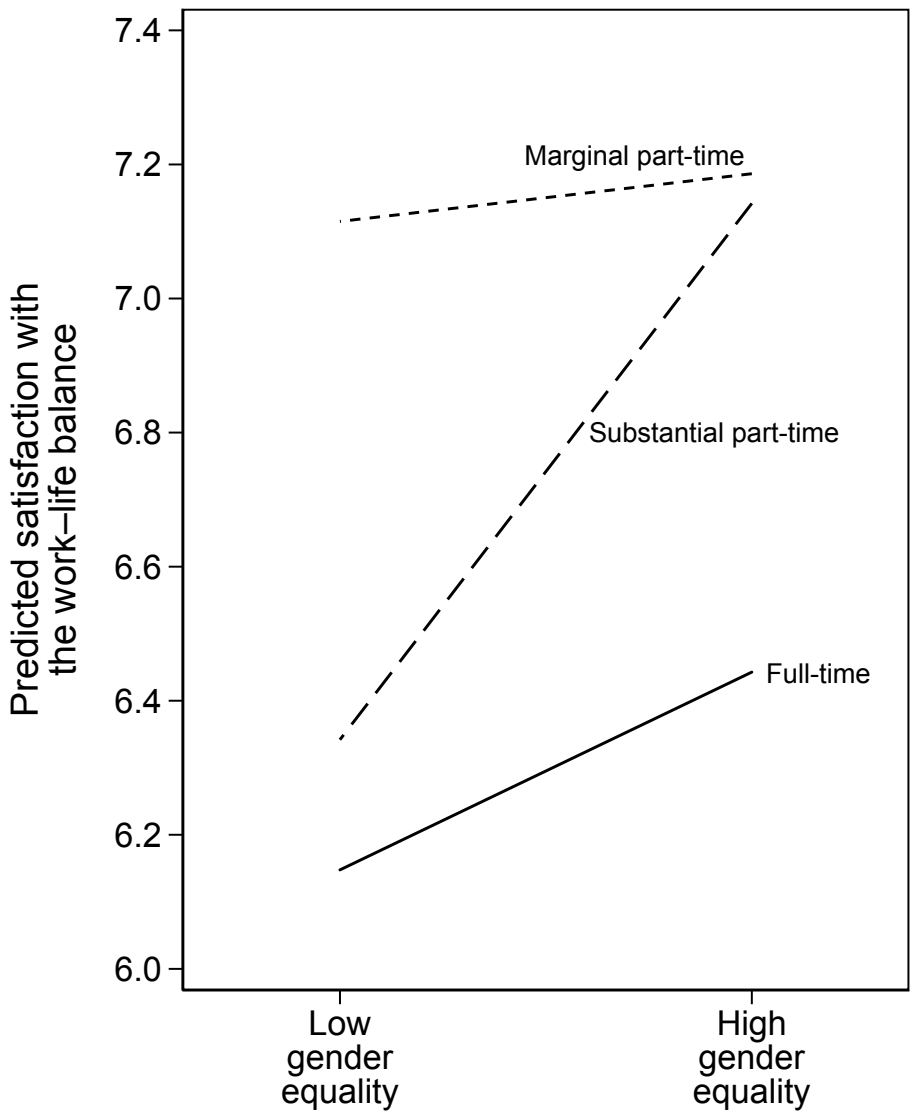

B

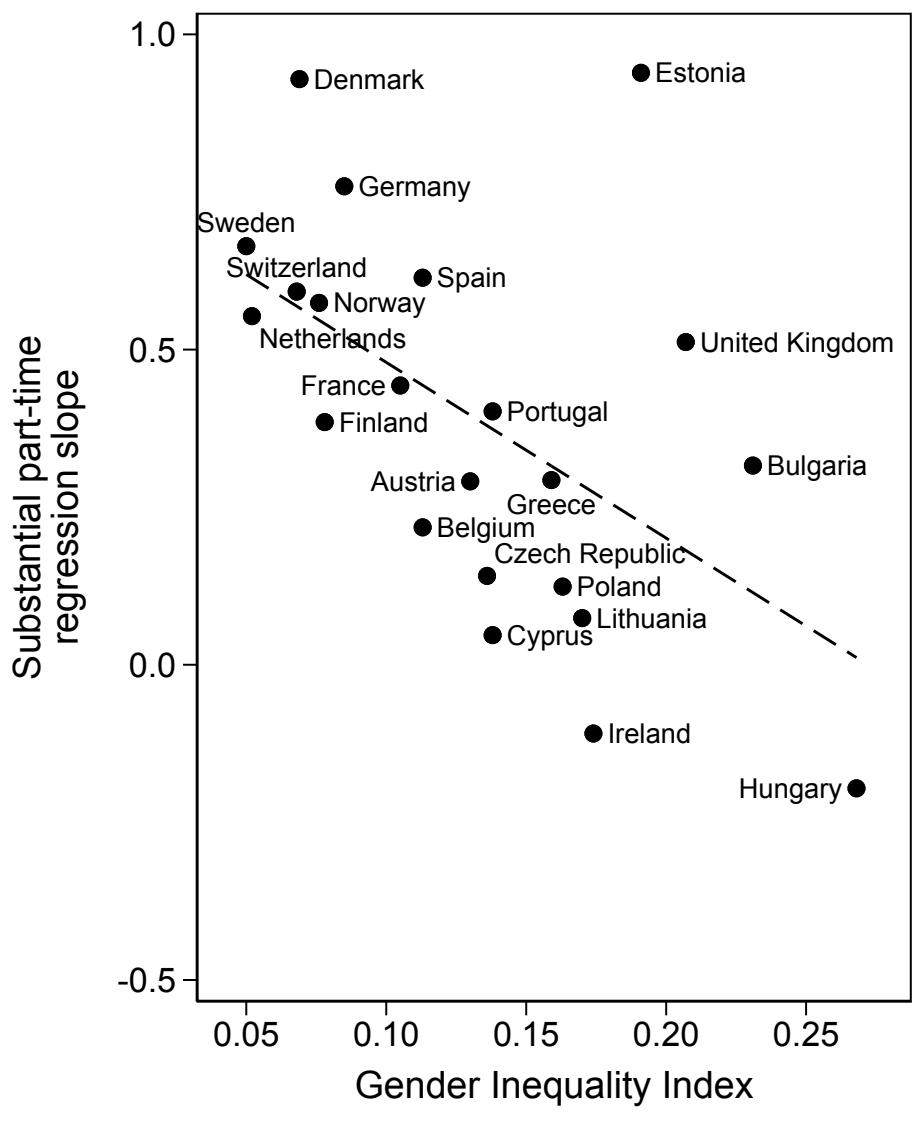

Figure 2: Panel A: Interaction plot of individual-level interaction with gender. Predictions based on Model 3 of Table 2. Panel B: Scatter plot for Gender Inequality Index and regression slope of marginal part-time work. Regression slopes obtained from country-specific regression models (available upon request)

Hypothesis 3 suggested that the differences in SWLB between full-time and part-time employees may also be at least partially explained by the level of gender equality at the country-level. Although the slope variances of our main predictors were non-significant in our models, we estimated the hypothesized crosslevel interactions following recommendations of LaHuis and Ferguson (2009). They recommend not using significant slope variance as a prerequisite for test- 
ing cross-level interactions but to test these interactions regardless of the slope variance. Consequently, in Model 3 country-level variables and the interaction terms GII $\times$ part-time marginal/substantial were added. None of the countrylevel variables had a significant main effect on employees' SWLB. Nevertheless, our analysis revealed a significant interaction for substantial part-time $\times$ GII on SWLB $(b=-2.52, p<.01)$, but not for marginal part-time work. Panel A of Figure 2 depicts that substantial part-time workers are more satisfied with their WLB than full-time workers at high levels of national gender equality. At low levels of national gender equality, there is little difference in levels of satisfaction between employees working full-time and those working substantial part-time. But the gap is wider in more gender-egalitarian countries. At all levels of national gender equality, marginal part-time workers are more satisfied with their WLB than full-time employees and substantial part-time workers, but the difference in SWLB between marginal and substantial part-time workers is smaller when a country is more gender-egalitarian.

To facilitate cross-national analysis and to visualize country-differences, the two-step regression analysis approach recommended by Bryan and Jenkins (2016) was applied. The substantial part-time slope coefficients of the within-country OLS regressions with SWLB as the outcome are plotted in Panel B of Figure 2. A positive slope for substantial part-time refers to higher SWLB for respondents working a substantial part-time schedule. Gender, age, marital status, having children, professional status, overtime, job demands and resources, and economic wellbeing were included as control variables in OLS regressions (analyses available upon request).

Panel B of Figure 2 confirms the pattern of our random coefficient models. Differences in SWLB between substantial part-time and full-time workers tend to be larger in the more gender-egalitarian countries (low GII score), such as The Netherlands, the Nordic countries, but also Switzerland and Germany. Countries with higher gender inequality are located at the lower end of the regression line, with even negative associations between substantial part-time work and SWLB in Hungary and Ireland. Two countries deviate from this overall pattern: in Estonia and to a smaller extent in the UK, working a substantial part-time schedule is strongly and positively related to SWLB despite a rather high GII Index (low gender equality).

\section{Discussion}

The main purpose of this study was to examine whether worker's gender and societal gender equality alter the link between part-time employment and satisfaction with work-life balance (SWLB). We thereby extended comparative research on part-time work and SWLB to a larger array of European coun- 
tries, and accounted for the heterogeneity of part-time arrangements. In line with the scarcity argument (Goode, 1960) and previous findings on part-time employment in the service sector in Western Europe (Beham et al., 2012), employees working marginal part-time were found reporting higher levels of SWLB than employees working a substantial part-time schedule. Despite the evidence of lower job quality and certain disadvantages of part-time jobs (e.g. Lyonette et al., 2010; Warren, 2004), which may be even more prevalent in marginal parttime arrangements, our findings suggest that a substantial reduction of working hours provides employees with better opportunities to juggle work and nonwork responsibilities, leading to higher SWLB. Nevertheless, the relationship between marginal part-time work and SWLB turns out to differ between men and women. Whereas no gender differences in SWLB were found for substantial part-time, women seem to benefit more from marginal part-time work in terms of increased levels of SWLB than men. If full-time employment is considered, we find exactly the opposite relationship. Male full-time workers seem to be more satisfied with their WLB than female full-time workers. These findings are in line with traditional gender roles and family models, as well as gender differences in the motivation to work part-time. In traditional family models men assume the role of the main breadwinner and women the role of the main caregiver. Consequently, women more frequently and often to a larger extent reduce their working hours for family and personal reasons, whereas men more often work part-time for education and training or due to the difficult labor market situation (Baierl and Kapella, 2014). Hence, despite growing expectations of men to become more engaged in household tasks and care-giving in some European countries (Fahlén, 2014), traditional gender roles and division of labor seem to prevail overall.

The results of our cross-level analysis support the need for considering the societal context when examining the work-family interface, since gender norms and social policies shape employees' opportunities for WLB. As predicted, substantial part-time workers experienced more SWLB in countries with less gender inequality, where societal norms and policies encourage a more egalitarian division of labor between men and women. At the same time, the difference in levels of SWLB between substantial part-time and full-time workers was much larger in these countries than in the less gender-egalitarian countries. We attribute these findings at least partially to heightened expectations for WLB in the more gender-egalitarian countries. Extensive public discourse on gender equality and generous support for WLB in these countries may lead to heightened expectations for less time at work and more WLB among workers (Ruppanner and Maume, 2016). If workers can match their expectations with a reduction in working hours, this may translate into increased levels of satisfaction.

We found that marginal part-time workers were more satisfied with their 
work-life balance than full-time workers and that this difference was similar across countries, regardless of how gender-equal they are. However, marginal and substantial part-time workers are more alike in their satisfaction levels in more gender-egalitarian countries, as shown in Figure 2, Panel A. This smaller gap may be explained by higher levels of statutory policies for work-life reconciliation in the more gender-egalitarian countries.

The two-step regression analysis, which corroborated the findings from our HLM models, provided visual interpretation of country differences. It revealed stronger relationships between substantial part-time work and SWLB in the more gender-egalitarian countries of Northern Europe and The Netherlands, but also in Switzerland and Germany. Family and personal responsibilities are the most common reasons for employees (and especially for women) in the Nordic countries to work part-time (Drange and Egeland, 2014). The long-standing public discourse on gender equality, in combination with a welfare state regime that provides extensive statutory support for families and encourages a dualearner model, leads to stronger preferences for longer part-time arrangements and heightened expectations for WLB (Corrigall and Konrad, 2007; Fahlén, 2014; Nordenmark, 2004; Ruppanner and Maume, 2016). A substantial parttime schedule may thus be the preferred employment arrangement to combine paid and unpaid work in the Nordic countries, thereby resulting in high levels of SWLB. Similarly, in The Netherlands, Switzerland, and Germany substantial part-timers are significantly more satisfied with their WLB than full-time workers, although these countries differ from the Nordic countries in terms of family policies and the preference to reduce working hours. Germany and The Netherlands are characterized by a more traditional family model, whereas Switzerland has a more market-oriented family policy model (Boye, 2011). Mothers in these three countries, for example, were found to have a higher preference for reducing their working hours than mothers in the Nordic countries (Pollmann-Schult, 2016). Nevertheless, all three countries are very gender-egalitarian (with The Netherlands, together with Sweden, having the lowest GII score), are economically affluent, and high-quality public childcare is either largely provided by the state (Netherlands, Germany) or can be purchased (Switzerland). Consequently, substantial part-time work in these countries seems to be a more deliberate and conscious choice, which translates into high levels of SWLB, comparable to those in the Nordic countries.

In contrast, some of the Eastern European countries such as Hungary and Bulgaria are located at the lower end of the regression line (Figure 2, Panel B). Both countries are characterized by very traditional gender norms, a clear gendered division of housework (Boye, 2011), and the highest GII Index in our sample. Part-time work is less common, less desirable, and in many cases less affordable than in the economically more affluent countries (Baierl and Kapella, 
2014; Sándor, 2013). Whereas in Bulgaria substantial part-time work has a small positive impact on employees' SWLB, employees in substantial part-time jobs in Hungary have even lower SWLB than those working full-time. In the Czech Republic and Poland, working a substantial part-time schedule only has a very small positive impact on employee's levels of SWLB. However, our regression analysis by country revealed a significant positive effect of marginal part-time work on SWLB in all Eastern European countries. Our findings seem to reflect the lack of adequate childcare support in these countries, which makes it more difficult to combine a substantial part-time schedule with family responsibilities. Almost all post-Communist countries have experienced retrenchments of family policies (e.g. in public childcare) after the transition to market economy (Boye, 2011).

Interestingly, there are two cases of apparently similar pairs of countries in terms of levels of gender equality, welfare state and social policies, but remarkable differences in SWLB among substantial part-time workers. These are the UK and Ireland, both representing the liberal, market-oriented welfare state, and the two Baltic States Estonia and Lithuania. Whereas both the UK and Ireland have lower gender equality than other Western European countries (which is reflected in higher GII scores), substantial part-time work is positively associated with SWLB in UK but negatively in Ireland. Country-specific regression analyses also revealed a positive effect of marginal part-time work on SWLB for both countries, but this link was particularly pronounced in the UK.

Likewise, the levels of SWLB between Estonian and Lithuanian workers in substantial part-time jobs differ remarkably, with much higher levels of SWLB in Estonia than in Lithuania. The Baltic States have not received much attention in work-family research and our knowledge on how employees in these states manage their work and family responsibilities is still limited. In both countries, part-time employment is significantly less prevalent than in Western and Northern Europe and full-time employment is preferred. However, Lithuania is the only Catholic country among the Baltic States, with people holding more traditional views on the family and the division of labor, while the majority of Estonians favor the dual-earner model (Michon, 2010; Toots and Backmann, 2010). These differences in attitudes may partially account for the differences between the two countries in our analysis.

A similar explanation may obtain for the divergent findings in the UK and Ireland. Whereas there is a lack of public childcare support in both countries, the negative association between substantial part-time work and SWLB in Ireland may be at least partially explained with very traditional gender roles resulting from Catholic familialism in Ireland (Lyonette, 2015; Russell et al., 2008).

As a bottom line, our findings overall support the argument that gender norms and family policies shape men's and women's expectations regarding 
WLB and their abilities to achieve a satisfying level of balance between the different life domains. Nevertheless, some limitations should be kept in mind when interpreting the results. The European Social Survey is composed of crosssectional national datasets. Such data can make causal conclusions difficult. Although findings are largely consistent with the assumed causal relationships in our theorizing, rival explanations for significant findings cannot be ruled out (Stone-Romero and Rosopa, 2007). Further, our outcome SWLB was assessed with a single item. Although it is debatable whether a multi-item measure, such as the one of Valcour (2007), yields a more robust and reliable assessments of an individual's level of SWLB, future studies may want to include a multiitem measure in addition to the single-item variable to account for potential differences in mean scores. We controlled for involuntary part-time employment at the country level since an individual level measure was not available in the dataset. However, future research may also want to account for involuntary part-time work at the individual level to better assess the gendered motivation for pursuing specific working time options over the life course.

\section{References}

Abendroth, Anja-Kristin and Laura den Dulk, 2011. 'Support for the Work-Life Balance in Europe. The Impact of State, Workplace, and Family Support on Work-Life Balance Satisfaction.' Work, Employment, and Society 25(2): 234-256. doi: 10.1177/0950017011398892.

Baierl, Andreas and Olaf Kapella, 2014. 'Trend zur Teilzeit. Bestandsaufnahme und Auswirkungen für Beruf und Familie.' Austrian Institute for Family Studies Working Paper 81.

Beham, Barbara and Sonja Drobnič, 2011. 'Job Demands and Work-Home Interference. Empirical Evidence from Service Sector Employees in Eight European Countries.' In Drobnič, Sonja and Ana M. Guillén, eds., Work-Life Balance in Europe. The Role of Job Quality, pp. 95-119. London: Palgrave Macmillan. doi: 10.1057/9780230307582_5.

Beham, Barbara, Sonja Drobnič, Patrick Präg, Andreas Baierl, and Suzan Lewis, 2018. 'Work-to-Family Enrichment and Gender Inequalities in Eight European Countries.' International Journal of Human Resource Management doi: 10.1080/09585192.2017.1355837.

Beham, Barbara, Sonja Drobnič, and Patrick Präg, 2011. 'Work Demands and Resources and the Work-Family Interface. Testing a Salience Model on German Service Sector Employees.' Journal of Vocational Behavior 78(1): 110-122. doi: $10.1016 /$ j.jvb.2010.07.008.

_, 2014 . 'The Work-Family Interface of Service Sector Workers. A Compar- 
ison of Work Resources and Professional Status across Five European Countries.' Applied Psychology 63(1): 29-61. doi: 10.1111/apps.12012.

Beham, Barbara, Patrick Präg, and Sonja Drobnič, 2012. 'Who's Got the Balance? A Study of Satisfaction with the Work-Family Balance among PartTime Service Sector Employees in Five Western European Countries.' International Journal of Human Resource Management 23(18): 3725-3741. doi: 10.1080/09585192.2012.654808.

Bielenski, Harald, Alexandra Wagner, and Gerhard Bosch, 2002. Working Time Preferences in Sixteen European Countries. Dublin: European Foundation for the Improvement of Living and Working Conditions.

Blossfeld, Hans-Peter and Catherine Hakim, 1997. Between Equalization and Marginalization. Women Working Part-Time in Europe and the United States of America. Oxford: Oxford University Press.

Boye, Katarina, 2011. 'Work and Wellbeing in a Comparative Perspective. The Role of Family Policy.' European Sociological Review 27(1): 16-30. doi: 10.1093/esr/jcp051.

Bryan, Mark L. and Stephen P. Jenkins, 2016. 'Multilevel Modeling of Country Effects. A Cautionary Tale.' European Sociological Review 32(1): 3-22. doi: $10.1093 /$ esr/jcv059.

Carlson, Dawn S., Joseph G. Grzywacz, and Suzanne Zivnuska, 2009. 'Is Work-Family Balance More than Conflict and Enrichment?' Human Relations 62(10): 1459-1486. doi: 10.1177/0018726709336500.

Corrigall, Elizabeth A. and Alison M. Konrad, 2007. 'Gender Role Attitudes and Careers. A Longitudinal Study.' Sex Roles 56(11): 847-855. doi: 10.1007/s11199-007-9242-0.

Drange, Ida and Cathrine Egeland, 2014. Part-Time Work in the Nordic Region II. A Research Review on Important Reasons. Copenhagen: Nordic Council of Ministers. doi: 10.6027/TN2014-560.

Drobnič, Sonja, 1997. 'Part-Time Work in Central and Eastern European Countries.' In Blossfeld, Hans-Peter and Catherine Hakim, eds., Between Equalization and Marginalization. Women Working Part-Time in Europe and the United States of America, pp. 71-89. Oxford: Oxford University Press.

Drobnič, Sonja and Ana M. Guillén Rodríguez, 2011. 'Tensions Between Work and Home. Job Quality and Working Conditions in the Institutional Contexts of Germany and Spain.' Social Politics 18(2): 232-268. doi: $10.1093 / \mathrm{sp} / \mathrm{jxr} 008$.

Erikson, Robert and John H. Goldthorpe, 1992. The Constant Flux. A Study of Class Mobility in Industrial Societies. Oxford: Clarendon.

Eurostat, 2018. Statistics Database. Luxembourg: European Commission.

Fahlén, Susanne, 2012. Facets of Work-Life Balance across Europe. How the Interplay of Institutional Contexts, Work Arrangements, and Individual Re- 
sources Affect Capabilities for Having a Family, and for Being Involved in Family Life. Stockholm: Acta Universitatis Stockholmiensis.

_ , 2014. 'Does Gender Matter? Policies, Norms, and the Gender Gap in Work-to-Home and Home-to-Work Conflict Across Europe.' Community, Work, and Family 17(4): 371-391. doi: 10.1080/13668803.2014.899486.

Gash, Vanessa, 2008. 'Preference or Constraint? Part-Time Workers' Transitions in Denmark, France, and the United Kingdom.' Work, Employment, and Society 22(4): 655-674. doi: 10.1177/0950017008096741.

Gash, Vanessa, Antje Mertens, and Laura Romeu Gordo, 2012. 'The Influence of Changing Hours of Work on Women's Life Satisfaction.' Manchester School 80(1): 51-74. doi: 10.1111/j.1467-9957.2011.02255.x.

Gaye, Amie, Jeni Klugman, Milorad Kovacevic, Sarah Twigg, and Eduardo Zambrano, 2010. 'Measuring Key Disparities in Human Development. The Gender Inequality Index.' Human Development Research Papers 2010/46: $1-37$.

Gelman, Andrew and Jennifer Hill, 2007. Data Analysis Using Regression and Multilevel/Hierarchical Models. Cambridge: Cambridge University Press. doi: 10.1017/CBO9780511790942.

Goode, William J., 1960. 'A Theory of Role Strain.' American Sociological Review 25(4): 483-496. doi: 10.2307/2092933.

Gornick, Janet C. and Alexandra Heron, 2006. 'The Regulation of Working Time as Work-Family Reconciliation Policy. Comparing Europe, Japan, and the United States.' Journal of Comparative Policy Analysis Research and Practice 8(2): 149-166. doi: 10.1080/13876980600682139.

Greenhaus, Jeffrey H. and Tammy D. Allen, 2011. 'Work-Family Balance. A Review and Extension of the Literature.' In Quick, James Campbell and Lois E. Tetrick, eds., Handbook of Occupational Health Psychology, pp. 165183. Washington, DC: American Psychological Association, 2nd edition.

Greenhaus, Jeffrey H. and Nicholas J. Beutell, 1985. 'Sources of Conflict between Work and Family Roles.' Academy of Management Review 10(1): 76-88. doi: 10.5465/AMR.1985.4277352.

Gregory, Abigail and Susan Milner, 2008. 'Work-Life Balance. A Matter of Choice?' Gender, Work, and Organization 16(1): 1-13. doi: 10.1111/j.14680432.2008.00429.x.

Grönlund, Anne and Ida Öun, 2010. 'Rethinking Work-Family Conflict. Dual-Earner Policies, Role Conflict, and Role Expansion in Western Europe.' Journal of European Social Policy 20(3): 179-195. doi: $10.1177 / 0958928710364431$.

Grzywacz, Joseph G. and Dawn S. Carlson, 2007. 'Conceptualizing Work-Family Balance. Implications for Practice and Research.' 
Advances in Developing Human Resources 9(4): 455-471. doi: $10.1177 / 1523422307305487$.

Hagqvist, Emma, Katja Gillander Gådin, and Mikael Nordenmark, 2017. 'Work-Family Conflict and Wellbeing across Europe. The Role of Gender Context.' Social Indicators Research 132(2): 785-797. doi: 10.1007/s11205016-1301-x.

Heisig, Jan Paul, Merlin Schaeffer, and Johannes Giesecke, 2017. 'The Costs of Simplicity. Why Multilevel Models May Benefit from Accounting for CrossCluster Differences in the Effects of Controls.' American Sociological Review 82(4): 796-827. doi: 10.1177/0003122417717901.

Kovacheva, Siyka, Anneke van Doorne-Huiskes, and Timo Anttila, 2011. 'The Institutional Context of the Quality of Life.' In Bäck-Wiklund, Margareta, Tanja van der Lippe, Laura den Dulk, and Anneke van DoorneHuiskes, eds., Quality of Life and Work in Europe. Theory, Practice, and Policy, pp. 32-54. Houndsmills, Basingstoke: Palgrave Macmillan. doi: 10.1057/9780230299443_3.

LaHuis, David M. and Matthew W. Ferguson, 2009. 'The Accuracy of Significance Tests for Slope Variance Components in Multilevel Random Coefficient Models.' Organizational Research Methods 12(3): 418-435. doi: $10.1177 / 1094428107308984$.

Lyness, Karen S. and Michael K. Judiesch, 2014. 'Gender Egalitarianism and Work-Life Balance for Managers. Multisource Perspectives in 36 Countries.' Applied Psychology 63(1): 96-129. doi: 10.1111/apps.12011.

Lyonette, Clare, 2015. 'Part-Time Work, Work-Life Balance, and Gender Equality.' Journal of Social Welfare and Family Law 37(3): 321-333. doi: 10.1080/09649069.2015.1081225.

Lyonette, Clare, Beate Baldauf, and Heike Behle, 2010. 'Quality' Part-Time Work. A Review of the Evidence. London: Government Equalities Office.

Mandel, Hadas, 2009. 'Configurations of Gender Inequality. The Consequences of Ideology and Public Policy.' British Journal of Sociology 60(4): 693-719. doi: 10.1111/j.1468-4446.2009.01271.x.

McDaniel, Anne E., 2008. 'Measuring Gender Egalitarianism. The Attitudinal Difference between Men and Women.' International Journal of Sociology 38(1): 58-80. doi: 10.2753/IJS0020-7659380103.

McNamara, Tay K., Marcie Pitt-Catsouphes, Christina Matz-Costa, Melissa Brown, and Monique P. Valcour, 2013. 'Across the Continuum of Satisfaction with Work-Family Balance. Work Hours, Flexibility-Fit, and Work-Family Culture.' Social Science Research 42(2): 283-298. doi: 10.1016/j.ssresearch.2012.10.002.

Michoń, Piotr, 2010. 'Stay at Home, Dear.' Mothers, Labor Markets, and State Policy in Poland and the Baltic States.' In Klenner, Christina and Simone 
Leiber, eds., Welfare States and Gender Inequality in Central and Eastern Europe, pp. 151-180. Brussels: ETUI.

Mills, Melinda and Patrick Präg, 2016. 'Methodological Advances in CrossNational Research. Multilevel Challenges and Solutions.' European Sociological Review 32(1): 1-2. doi: 10.1093/esr/jcw009.

Mills, Melinda, Patrick Präg, Flavia Tsang, Katia Begall, James Derbyshire, Laura Kohle, Céline Miani, and Stijn Hoorens, 2014a. Use of Childcare Services in the EU Member States and Progress Towards the Barcelona Targets. Brussels: European Commission DG Justice. doi: 10.2838/54302.

Mills, Melinda, Flavia Tsang, Patrick Präg, Kai Ruggeri, Céline Miani, and Stijn Hoorens, 2014b. Gender Equality in the Workforce. Reconciling Work, Private, and Family Life in Europe. Brussels: European Commission DG Justice. doi: 10.2838/54302.

Nordenmark, Mikael, 2004. 'Does Gender Ideology Explain Differences Between Countries Regarding the Involvement of Women and of Men in Paid and Unpaid Work?' International Journal of Social Welfare 13(3): 233-243. doi: 10.1111/j.1369-6866.2004.00317.x.

OECD, 2018. Involuntary Part-Time Workers. Incidence. Paris: Organisation for Economic Co-Operation and Development. doi: 10.1787/data-00308-en.

Oishi, Akiko Sato, Raymond K. H. Chan, Lillian Lih-Rong Wang, and Ju-Hyun Kim, 2015. 'Do Part-Time Jobs Mitigate Workers' Work-Family Conflict and Enhance Wellbeing? New Evidence from Four East Asian Societies.' Social Indicators Research 121(1): 5-25. doi: 10.1007/s11205-014-0624-8.

Ollier-Malaterre, Ariane, Monique P. Valcour, Laura Den Dulk, and Ellen Ernst Kossek, 2013. 'Theorizing National Context to Develop Comparative Work-Life Research. A Review and Research Agenda.' European Management Journal 31(1): 433-447. doi: 10.1016/j.emj.2013.05.002.

Pfau-Effinger, Birgit, 2012. 'Women's Employment in the Institutional and Cultural Context.' International Journal of Sociology and Social Policy 32(9/10): 530-543. doi: 10.1108/01443331211257634.

Pollmann-Schult, Matthias, 2016. 'What Mothers Want. The Impact of Structural and Cultural Factors on Mothers' Preferred Working Hours in Western Europe.' Advances in Life Course Research 29: 16-25. doi: 10.1016/j.alcr.2015.11.002.

Präg, Patrick and Melinda Mills, 2014. Family-Related Working Schedule Flexibility across Europe. Cambridge: Rand Corporation. doi: 10.2838/54302.

Roeters, Anne and Lyn Craig, 2014. 'Part-Time Work, Women's Work-Life Conflict, and Job Satisfaction. A Cross-National Comparison of Australia, The Netherlands, Germany, Sweden, and the United Kingdom.' International Journal of Comparative Sociology 55(3): 185-203. doi: 10.1177/0020715214543541. 
Rosenfeld, Rachel A. and Gunn Elisabeth Birkelund, 1995. 'Women's Part-Time Work. A Cross-National Comparison.' European Sociological Review 11(2): 111-134. doi: 10.1093/oxfordjournals.esr.a036352.

Ruppanner, Leah and Matt L. Huffman, 2014. 'Blurred Boundaries. Gender and Work-Family Interference in Cross-National Context.' Work and Occupations 41(2): 210-236. doi: 10.1177/0730888413500679.

Ruppanner, Leah and David J. Maume, 2016. 'Shorter Work Hours and Workto-Family Interference. Surprising Findings from 32 Countries.' Social Forces 95(2): 693-720. doi: 10.1093/sf/sow057.

Russell, Helen, J. O'Connell Philip, and Frances McGinnity, 2008. 'The Impact of Flexible Working Arrangements on Work-Life Conflict and Work Pressure in Ireland.' Gender, Work, and Organization 16(1): 73-97. doi: 10.1111/j.1468-0432.2008.00431.x.

Sándor, Eszter, 2013. Part-Time Work in Europe. Dublin: European Foundation for the Improvement of Living and Working Conditions. doi: 10.2806/116h.

Stone-Romero, Eugene F. and Patrick J. Rosopa, 2007. 'The Relative Validity of Inferences About Mediation as a Function of Research Design Characteristics.' Organizational Research Methods 11(2): 326-352. doi: 10.1177/1094428107300342.

Toots, Anu and Janika Backmann, 2010. 'Contemporary Welfare Regimes in Baltic States. Adapting Post-Communist Conditions to Post-Modern Challenges.' Studies of Transition States and Societies 2(2): 31-44.

Treas, Judith and Sonja Drobnič, 2010. Dividing the Domestic. Men, Women, and Household Work in Cross-National Perspective. Stanford, CA: Stanford University Press. doi: 10.11126/stanford/9780804763578.001.0001.

Treas, Judith, Tanja van der Lippe, and Tsui-o Chloe Tai, 2011. 'The Happy Homemaker? Married Women's Well-Being in Cross-National Perspective.' Social Forces 90(1): 111-132. doi: 10.1093/sf/90.1.111.

UNDP, 2010. Human Development Report. The Real Wealth of Nations. Pathways to Human Development. Houndmills, Basingstoke: Palgrave Macmillan.

Uunk, Wilfred, 2015. 'Does the Cultural Context Matter? The Effect of a Country's Gender Role Attitudes on Female Labor Supply.' European Societies 17(2): 176-198. doi: 10.1080/14616696.2014.995772.

Valcour, Monique P., 2007. 'Work-Based Resources as Moderators of the Relationship between Work Hours and Satisfaction with Work-Family Balance.' Journal of Applied Psychology 92(6): 1512-1523. doi: 10.1037/00219010.92.6.1512.

Warren, Tracey, 2004. 'Working Part-Time. Achieving a Successful Work-Life Balance?' British Journal of Sociology 55(1): 99-122. doi: 10.1111/j.14684446.2004.00008.x. 
- 2008. 'Universal Disadvantage? The Economic Wellbeing of Female Part-Timers in Europe.' European Societies 10(5): 737-762. doi: $10.1080 / 14616690701757853$.

Wayne, Julie Holliday, Marcus M. Butts, Wendy J. Casper, and Tammy D. Allen, 2017. 'In Search of Balance. A Conceptual and Empirical Integration of Multiple Meanings of Work-Family Balance.' Personnel Psychology 70(1): 167-210. doi: 10.1111/peps.12132.

Webber, Gretchen and Christine Williams, 2008. 'Mothers in 'Good' and 'Bad' Part-Time Jobs. Different Problems, Same Results.' Gender and Society 22(6): 752-777. doi: 10.1177/0891243208325698. 